\title{
Feature
}

\section{Fictions of Composition in the Novels of David Mitchell}

\author{
Lisa McNally
}

WHEN I FIRST WROTE THIS ESSAY, it contained a number of references to Roland Barthes and Jacques Derrida. I aligned composition with the notion of the 'writerly' established in $S / Z$ and which Barthes privileges as 'our value.'. The writerly is, for $S / Z$, the 'perpetual present' of 'ourselves writing'; Barthes explains that 'The writerly is the novelistic without the novel, poetry without the poem, the essay without the dissertation, writing without style, production without product, structuration without structure.' ${ }^{3}$ The writerly is aligned with process and a notion of writing as event. Reading this list, however, we realise that it will remain unattainable: how could we ever isolate production from the product it produces? How could we locate a production which produced nothing?

Maurice Blanchot, although like Barthes aligning the 'movement that leads to' the work, rather than the work itself, with 'truth', stresses more explicitly that this 'movement' cannot be unproblematically attained. He claims that 'the work counts less than the experience of the search for it $[\ldots]$ an artist is always ready to sacrifice the work's accomplishment to the truth of the movement that leads to it'. ${ }^{4}$ In order to render its 'movement' the work would have to 'sacrifice' itself; impossibly, it would have to forfeit its status as a work. Fully conscious of this paradox, Derrida's 'Force and Signification' demands, 
according to Sarah Wood, that we go 'all the way to writing. ${ }^{5}$ Wood explores this exhortation in her essay of the same title and it does not take long to realise that 'really there is no moment of writing, no simple present or presence'. ${ }^{6} \mathrm{We}$ cannot ever reach writing; we fail to capture its moment. Why, then, does Derrida send us that way? Although we cannot grasp writing, we notice, with Wood, that it is 'about. Outside. Around. In the offing.' ${ }^{7}$ Although writing's pure presence is inaccessible, we may nonetheless glimpse its impossible instance; a different mode of reading-such as that demonstrated throughout Derrida's work-may tease out writing's traces.

My article enacts this realisation as it considers the way in which David Mitchell's novels represent composition. In my first draft, my argument was supported throughout by the above references to Barthes, Derrida and Wood. As I revised it, however, I began to wonder about its emphasis. I set out to write an article which was both about Mitchell's novels and, equally, a 'deconstruction' of writing following Derrida. Yet Derrida, as the more academically established figure, inevitably tipped the balance; despite my intentions, my reading of Mitchell's novels appeared subservient to Derrida's theory. If my analysis of Mitchell's novels was to stand as a reading in its own right, Derrida would have to go. I decided to erase the references to his work. Although my exposition remains indebted to him, he is no longer mentioned explicitly here, in my final version.

Many of the characters in Mitchell's novels are writers. In the London section of Ghostwritten we meet Marco, a 'ghostwriter' who informs, us, 'I'm currently writing the life story of this old guy Alfred [...] I go, he reminisces about his younger days, I tape it, jot notes and by next week I write it up into a narrative.' ${ }^{8}$ In number9dream's 'Study of Tales' Eiji stays in the house of Mrs Sasaki's sister, who is a writer although, as Mrs Sasaki points out, she prefers the term 'fabulist'. ${ }^{9}$ During his stay, Eiji reads a series of tales she has written which thematize, yet again, the act of authorship through their protagonist, Goatwriter. Jason, the protagonist of Black Swan Green, is also a writer; specifically, he is a young poet whose work is published in the parish newsletter under the pseudonym Eliot Bolivar. ${ }^{10}$ Thomas Jones describes the novel as the 'story of a stammering poet finding his true voice as a writer of fluent prose.' And in Cloud Atlas Adam Ewing, Robert Frobisher and Tim Cavendish are in the process of composing a diary, letters and a memoir respectively.

Thus, Mitchell's novels repeatedly write about writing. They contain 'metafictional musings', as Stephen Abell notes of Cloud Atlas. ${ }^{12}$ This double gesture is not, of course, unique; moreover, it is frequently celebrated as sophisticated. For Patricia Waugh, for example, 'metafiction' indicates that 'the novel has reached a mature recognition of its existence as writing. ${ }^{13}$ Waugh frames the self-consciousness of these novels as their coming-of-age; she implies that, through them, the novel finally recognises its written form, attaining a self-awareness it previously lacked. Mitchell's novels, too, present 
these moments as remarkable. Ghostwritten's London section opens with a scene in which Marco wakes up after a drunken night next to a woman whose name he cannot remember. She notices, and re-introduces herself as Katy Forbes. Marco begins to tell her his name, but she cuts him off, retorting, 'Marco. I know. The "writer". We did just about get to the name swapping stage.' Marco muses 'so I'd played the writer card. That was valuable information' ( $G$ 266). My essay, too, will show that these writerly moments are 'valuable'. However, the information they convey is not simple and is not an unproblematically 'mature' self-knowing. These novels claim to represent writing as it takes place. However, the acts of composition they depict are fictional; the actual writing by which they are composed takes place elsewhere. By representing writing within novels which are themselves composed by a similar process of writing, they deny it a single or stable appearance. Composition remains an elusive and troubling moment which cannot be simply grasped. Nonetheless, this failure places the moment of reading into relief; our inability to capture writing forces us to consider the possibility of reading.

\section{Moments of Composition}

number9dream depicts the act of writing as 'Goatwriter sat down at his writing bureau. Luscious sentences swirled inches about his head, waiting for him to put them onto paper' ( $n 9 d$ 237). In stark contrast to the romantic fable of Goatwriter's swirling 'luscious sentences', Jason in Black Swan Green offers a series of banal vignettes. He writes, 'then I got sucked into a poem about a skater on a frozen lake who wants to know what it's like to be dead so much, he's persuaded himself that a drowned kid's talking to him. I typed it out on my Silver Reed Elan 20 Manual Typewriter' (BSG 41); and, later, 'I doodled for a bit (if you pretend not to look for words they come out of the thickets) but my Biro died' (BSG 283). Jason's overly specific reference to his 'Silver Reed Elan 20 Manual Typewriter' and his mention of a tool as mundane as a 'Biro' contrast with the poetry he composes, generating in both cases a comic anticlimax as the literary and the mundane converge.

Despite the difference in tone, both the mention of Goatwriter's 'writing bureau' and Jason's allusion to his typewriter invoke the circumstances surrounding the composition of their texts. Similarly, in Cloud Atlas's 'The Ghastly Ordeal' Cavendish declares 'I could still taste it. I can still taste it as I write these words ${ }^{, 14}$; and in number9dream Subaru Tsukiyama, a World War II kamikaze pilot, announces in his diary 'I am writing these words to distract my mind' (n9d 304). These writer-characters inform us of the conditions under which they write and of the decisions they make as they compose their texts. As Ewing in 'The Pacific Journal' recounts his meeting with Autua, a stowaway he finds in his cabin, he explains that 'His pidgin delivered his tale brokenly so its substance only shall I endeavour to set down here' (CA 30). For Ewing, it is impractical to transpose Autua's 'broken' account exactly; he refers us to the dilemma that faces him: how should he best transpose these events into writing? He later writes 'my quill curls at recording his profanity', leaving a blank where this 'profanity' would be (CA 25). Ghostwritten displays a similar 
awareness when Marco finds himself in a casino playing roulette. As he watches the wheel spin he asks,

What's the ball like, ghostwriter? Give us a metaphor.

Very well. It's like a genie, spending its fury until nothing is left. (G 3I0)

Marco's 'What's the ball like?' anticipates the choice he must make concerning the language he will use. Again, he emphasises the way in which the narrative is told and the manner in which he decides to write it.

Each of these texts refers to writing as though it were taking place, alluding to it in the present tense. In Cloud Atlas's 'The Pacific Journal', Ewing repeats the phrase 'as I write'; he announces, 'A new mizzen-top is being hoisted into position as I write', 'The consultation continues as I write' and 'Even as I write these words, I am tearful with gratitude' (CA 11, 17, 37). Ewing both writes about events and writes about the fact that he is writing them. The narrative alludes to the time of its writing and, as such, progresses as though Ewing were the author of the text that we read; he refers to 'this journal' and 'this diary' $(C A 7,28)$. A similar situation unfolds in 'Letters from Zedelghem' as Frobisher writes and refers to 'these pages' (CA 72).

These texts purport to unfold writing as it happens, depicting its moment or present and thereby claiming to represent the composition which precedes the composed. In 'The Ghastly Ordeal', for example, Cavendish announces, a few pages into his narrative, 'The Ghastly Ordeal of Timothy Cavendish, if you will. Now that is a snappy title' (CA 149). Cavendish inscribes the point of inspiration, writing and rejoicing at the moment at which the title of the text occurs to him. 'The Ghastly Ordeal' proceeds as Cavendish composes the text that we read and, although it begins in a conventional manner, Cavendish interrupts his narrative after a few pages to exclaim

Odd how the wrong stories pop into one's head at my age.

It's not odd, no, it's ruddy scary. I meant to begin this narrative with Dermot Hoggins. (CA |48)

He then re-starts his narrative with the 'correct' story. Cavendish reflects upon this messy re-beginning and complains 'that's the problem with inking one's memoirs in longhand. You can't go changing what you've already set down, not without botching things up even more' (CA 148). Cavendish presents his text as a draft which includes his errors and revisions, displaying a disarray the finished product would mask. When Marco arrives at Alfred's house in Ghostwritten he is greeted by Alfred's boyfriend, Roy. Marco writes, in sentences laden with double-entendre, that 'Roy insists on helping me off with my coat, and slings it over the pineapple-shaped knob of the banister. I must look up the correct word for that knob' (G 281). Marco's mental note to 'look up the correct word' accords the 'pineapple-shaped knob' phrase a temporary status; it implies that the text is unpolished and incomplete. The comments made by Marco and Cavendish, presenting these writings as unfinished, do not belong in a composed text. 
Their claims are, however, clearly untrue; the text is published and whole. Although Marco and Cavendish assert that the process of writing is ongoing, we know that this assertion is feigned. Moreover, Marco and Cavendish pretend to author the work we read, but we know that David Mitchell has written it. Writing does not actually 'happen' as these texts claim; their declarations are undone by the writing in which they occur and by the reading to which they are subjected. The moment of composition remains elusive, as I will show in the next section of my article before returning in my final section to the question of reading.

\section{Fictions of Composition}

My previous section mentioned the way in which Marco apparently composes the London section of Ghostwritten. In addition, the correspondence between his profession as ghostwriter and the novel's title accords him a central role; Marco is the supposed author not only of 'London', but of the entire novel, which is formed of multiple sections each containing a different narrative. Although mostly independent, these narratives refer subtly to each other. Marco's narrative contains more of these allusions than any other section. For example, after Marco wakes up in the house of Katy Forbes, a Queen Anne chair arrives and Katy explains that it has been shipped from Hong Kong following her husband's death. These details appear in the novel's earlier 'Hong Kong' section. There, we read of an English businessman living in Hong Kong whose estranged wife, Katy Forbes, has moved back to England and calls to demand that he return her Queen Anne chair. At the end of the section, he dies. This pattern is repeated. Later, Marco visits Alfred. Again, there is an unexpected arrival: Roy rushes in to announce that their friend, Jerome, has died. Once more, we have already read about the event to which Roy refersJerome's death is contextualised in the earlier Petersburg section.

We are led to believe that each section of the novel is a fiction prompted by the snippets Marco sees and overhears. Marco, it is implied, constructs each of the novel's narratives from the stories he glimpses; each of these narratives is the product of his imagination. However, both the Hong Kong and Petersburg sections precede the London section in which Marco appears; we read them before we reach Marco's narrative. Thus, we read these accounts first and only belatedly learn of Marco's involvement. This belated admission highlights a troubling fact: during our first reading, Marco is invisible; he ghostwrites each of Ghostwritten's narratives. His writing masks itself.

In Cloud Atlas, too, the act of writing is revealed after the event. The second section of 'The Ghastly Ordeal' opens with a series of disjointed scenes:

'Mr Cavendish? Are we awake?' A liquorice snake on a field of cream wriggles into focus. The number five. November $5^{\text {th }}$. Why does my old John Thomas hurt so? (CA 369)

Employing the present tense, Cavendish narrates the disorientation following his stroke. After these scenes he writes, 'I offer that trio of vignettes for the 
benefit of lucky readers whose psyches have never been razed to rubble by blood capillaries rupturing in their brains' (CA 370). The previous scenes do not, in fact, depict Cavendish's mental disintegration as it takes place but are, of course, a 'trio of vignettes' crafted after the event; it would not have been possible for Cavendish to record the events as they happened. However, he admits this impossibility only after he has presented us his present-tense account.

In both of these examples, the act of writing is not at first apparent but is retroactively conferred upon the writing we have read previously. The term 'ghostwritten' evokes this invisibility: a ghostwritten text hides its true authorship, concealing the writing by which it is formed. Ghostwriting is not exceptional, however, but highlights a general condition; in Ghostwritten, Cavendish quips to Marco, 'we're all ghostwriters, my boy'. Every text masks its composition; we can contemplate its origin only after it has been presented, as Cloud Atlas demonstrates. The novel's first section, 'The Pacific Diary of Adam Ewing', progresses as though Ewing were its author. Part way through the diary, however, we encounter a footnote which reads, 'My father never spoke to me of the dendroglyphs \& I learnt of them only in the manner described in the Introduction', and which is signed 'J.E' (CA 21). We learn that 'J.E', a different author invisible until this point, has also contributed to the text's composition.

A little later in the novel, however, 'The Pacific Diary' breaks off midsentence and a new section begins. This section, entitled 'Letters from Zedelghem', is apparently unrelated to the first. Soon, however, the author of these letters, Robert Frobisher, finds a 'curious dismembered volume' (CA 64). He describes the book: 'From what little I can glean, it's the edited journal of a voyage from Sydney to California by a notary of San Francisco named Adam Ewing. The journal seems to be published posthumously, by Ewing's son (?)'. It becomes clear that it is the Diary we have just read.

Frobisher comments that there is 'something shifty about the journal's authenticity - seems too structured for a genuine diary, and its language doesn't quite ring true-but who would bother forging such a journal, and why?' (CA 64). Frobisher belatedly alerts us to 'something shifty'; it is unlikely that Ewing is the true author of the text. Ewing refers to an act of writing but it is not, in fact, the writing by which the text is composed. Similar shifts in emphasis occur in Ghostwritten and Black Swan Green. Our ghostwriter Marco wonders 'Was I in a tragedy or a farce?' and comments 'This all seemed choreographed' (G 288, 315). The novel thus alludes to Marco's position within a choreographed tragedy or a farce while Black Swan Green's author-character, Jason, announces: 'There's tons of stories where bad things happen to strangers who help themselves to food and drink' and thereby refers to his status as a figure within a story (BSG 118). Both Jason and Marco are, of course, fictional characters and their authorship is a fabrication.

In Cloud Atlas, Frobisher dismisses the composition to which Ewing refers as a fiction and refers us to a different origin for 'The Pacific Journal'. The origin Frobisher posits is, however, similarly problematic. Like 'The Pacific Diary', Frobisher's text ends suddenly and is replaced by the novel's next section, 'The First Luisa Rey Mystery'. Again, Frobisher's letters reappear within this section: 'In his hotel room at the Bon Voyage, Dr Rufus Sixsmith 
reads a sheaf of letters written to him nearly half a century ago by his friend Robert Frobisher. Sixsmith knows them by heart, but their texture, rustle and his friend's faded handwriting calm his nerves. These letters are what he would save from a burning building' (CA 112). In this case, the veracity of the novel's previous section is not questioned. However, the narrative in which Frobisher's letters now appear is evidently fictional; its title marks it as a detective story. The existence of these letters within this fictional text implies that they, too, are created as fiction.

Frobisher points to the fictional composition of Ewing's text in a text which is, again, fictionally composed. The novel's attempt to capture the moment of composition engages it in an inevitable proliferation. Behind each writing lies yet another act of composition for which, in turn, the novel must account. Composition's admission is always belated and, bound to take place again in writing, inseparable from the logic it declares. We are caught in the dilemma represented most notably in a much earlier novel, Laurence Sterne's Tristram Shandy. Tristram promises to narrate the entirety of his life, but as he writes his account he engages in a further activity, writing, which he is bound, also, to narrate. Unable to catch up with himself, he realises that 'at this rate I should just live 364 times faster than I should write. ${ }^{15}$ By writing about his writing, he generates yet more writing about which he must also write. The project is endless and impossible; Tristram cannot escape or halt his life in order to narrate it.

Black Swan Green also highlights this limitless deferral. Its protagonist, Jason, sits down at his desk intending to write a poem although the result, he admits, is more of a 'confession' (BSG 331). It opens: 'That ace song Olive's Salami by Elvis Costello and the Attractions'. We have read these words before. Jason's confession duplicates the opening of an earlier chapter entitled 'Goose Fair' (BSG 307). It continues for a few lines before Jason concludes, 'and on it went', thus implying that his confession continues. If we want to read its entirety, we should reread the earlier chapter. But when does Jason's writing stop? Nothing marks its end. If we continue to read we return once again to the point at which Jason begins his 'confession'. We are caught in a loop; Jason writes his confession and, as he writes, he recalls the moment at which he began to write and thus begins once again to write his confession. And so on, ad infinitum. Black Swan Green attempts to isolate the moment at which Jason begins to write, but cannot. It belatedly offers an account of its origin, but cannot grasp the instance to which it refers.

Each of these novels shows that composition cannot be captured; the composition we would represent does not exist independently from the composed we would dismiss and the moment of writing moves ever further away. Adam Ewing invokes this infinite structure when he writes that 'occasionally, I glimpse a truer Truth hiding in imperfect simulacrums of itself, but as I approach it, it bestirs itself \& moves deeper into the thorny swamp of dissent' (CA 17). We attempt to 'grasp' the moment of writing, but it escapes. We cannot catch up with 'truth' or reach the heart of the 'thorny swamp'. This impossibility demands that we rethink our approach.

We will never be able to render writing fully present. Nonetheless, Ewing's 'I glimpse' and 'I approach' emphasize his position in relation to the truth of 
which he speaks; as it moves away, the infinite regress places his stance into relief. Black Swan Green compounds this sense when Jason asks 'Do spirals end? Or just get so tiny your eyes can't follow any more?' (BSG 231). The uncanny quality of the spiral lies in this uncertainty; we cannot witness its increasing distance without questioning our own position. In this case, equally, our dilemma highlights our stance as readers. We cannot grasp writing, but in our failure reading becomes apparent. The impossible moment of writing refers us to our moment of reading, as I will show in my final section.

\section{Reading Composition, Composing Reading}

I mentioned earlier the moment at which Frobisher questions the origin of Ewing's text, when he claims that there is 'something shifty' about its authenticity. This is not, in fact, much of a revelation. Even as we read Ewing's text we are conscious that its origin cannot be that which he claims. Ewing writes, 'I have worn away a nib in narrating the day's excitements. It is grown too dark to see' (CA 36). Ewing refers to a diary written in ink and by hand. Timothy Cavendish, too, alludes to a text 'inked in longhand'; in number9dream Eiji reads a diary in which 'the pencil lines are fading away to ghost lines' ( $n 9 \mathrm{~d}$ 281); and in 'Letters from Zedelghem' Frobisher complains 'from now plain old Crommelynck shall have to do or I'll run out of ink' (CA 53). The texts we encounter in these novels are, however, printed.

It becomes clear that the texts we read are not the artefacts to which these characters refer; a footnote in 'The Pacific Journal' informs us: 'Here my father's handwriting slips into spasmodic illegibility-J.E' (CA 521). The writing the novel cites would not be that which we could read. Again in number9dream, Eiji, prefacing the final diary entry, explains 'I lie on my futon and begin decoding the final three pages of the journal. They are written on different paper, in cramped letters that get harder and harder to read' ( $n 9 d$ 314). When Eiji is first given the diary he is told, 'Look, your grandfather wants you to read this' ( $n 9 d$ 274). As he does so, the diary entries appear in the novel in full; we read them as Eiji does. He later tells us, however, that 'many of the kanji are obscure, so I have to keep referring to a dictionary' ( $n 9 d 281$ ). The diary entries we read are in English; that to which Eiji refers is, on the other hand, written in Japanese. Our reading would not have been possible were 'Eiji' not translating and rewriting the diary.

The writing to which the novel refers is not directly present to us. It is nonetheless legible as we read about it. Eiji's mother writes,

I mean-

-you can tell from the creases, can't you, I just scrunched this up and threw it at the bin. (n9d 74)

We do not 'see' the creases as Eiji's mother expects. Nevertheless, her comment makes them visible to us. Earlier, she remarks, 'New ink, new pen. Pretty dramatic point for my pen to die' ( $n 9 d$ 73). For the reader, of course, the text continues uninterrupted; we do not witness the pen die. Equally, Frobisher 
informs us in 'Letters from Zedelghem', 'Forgot about this unfinished letter, well $1 / 2$ forgot, it got buried under my piano MS \& too busy composing to fish it out' (CA 485); and in number9dream Subaru begs his addressee, Takara, to 'Forgive the long silence' ( $n 9 d$ 278). These claims are at odds with the time in which we read; neither the delay nor the silence is apparent to us before they are invoked. In the letter Eiji's mother writes, the point would not be dramatic if she did not pause to tell us 'new ink. New pen'; her pause constitutes, however, the 'dramatic point' of an interruption. The drama locates itself not at the moment at which the pen dies but at the later point (which nonetheless projects itself backwards), at which we are told of this death. We see the pen die, but only after its death has occurred.

A disjunction exists between the time of writing and the time of our reading. I mentioned earlier the moment midway through his text when Cavendish announces its title, when he announces 'the Ghastly Ordeal of Timothy Cavendish, if you will. Now that is a snappy title' (CA 149). The title of the work occurs to Cavendish as he composes his text. This is perfectly logical: although the title begins the text, it is not necessarily composed first. Cavendish's celebration occurs at the time of writing. However, we do not share the thrill of his sudden inspiration. We have already read the text's title, on its opening page; for us as readers the title is no longer new and its appearance does not carry the same force. In reading, the time of writing is lost and what Cavendish writes as present, we read as past.

We do not read a present writing, but always that which has been written. By the time we read, writing is complete; the act of reading announces that writing is past. This is especially apparent in the letter Eiji's mother writes in number9dream. Following the conventional prefatory material, it opens with the words:

How do I begin this? I already wrote a stroppy letter, then a moaning one, then a witty one that began, 'Hello, I am your mother, nice to meet you'. Then one that began with 'Sorry'. They are scrunched up, near the bin on the other side of my room. I am a lousy shot. (n9d 7I)

Somewhat paradoxically, the 'how do I begin?' begins the text; it initiates the letter even before it has decided how it might start.

Similarly, when Cavendish re-starts his narrative in 'The Ghastly Ordeal', emphasizing the Dermot Hoggins affair as the true beginning of his account, he writes, 'As an experienced editor I disapprove of backflashes, foreshadowings and tricky devices, they belong in the 1980s with MAs in Postmodernism and Chaos Theory. I make no apology, however, for (re)starting my own narrative with my version of that shocking affair' (CA 152). The graphology of Cavendish's '(re)starting' is evidently a jibe at the 'tricky devices' of 'MAs in Postmodernism and Chaos Theory'; however, it is also telling. Even though Cavendish claims to revise his text, its beginning remains unchanged; we still read the text's beginning as the first page of 'The Ghastly Ordeal'. Although it represents a new beginning, the story of Dermot Hoggins does not begin the text anew. Although Cavendish claims to re-start his narrative, the text of our 
reading begins only once. We cannot allude in writing to the beforehand with which composition is aligned.

Reading and writing do not occur at the same time and neither is fully present to the other; each occurs in the absence of the other and they do not and cannot take place at the same instant. The moment of writing is always and inevitably resituated at and by the moment of reading. Yet without this compromising deferral, neither would be possible. In number9dream Mrs Sasaki retorts that 'Unread stories aren't stories' ( $n 9 d$ 228). The story is not a story until it is read; reading belatedly and retroactively confers its status. Writing depends for its sense upon the very reading which compromises its specificity, as is shown most poignantly by the final letter Frobisher writes in Cloud Atlas. Frobisher's letter opens:

Sixsmith,

Shot myself through the roof of my mouth at 5 a.m. this morning with V.A.'s Luger. (CA 487)

Unusually, Frobisher reports his death in the past tense. This is of course impossible; the act of writing proves that he is alive. As Frobisher writes, neither his death nor Sixsmith's reading has yet occurred. The announcement is all the more dramatic for this incongruity. Frobisher's past tense anticipates the future moment of reading; he employs the tense in which Sixsmith will read his letter. In number9dream, too, Subaru writes in his opening entry, 'By the time you read these words, Mother will have already received a telegram informing you of my death' (n9d 275). Subaru employs the future perfect 'will have already received' in order to pattern the convoluted oscillation between reading and writing. He too anticipates the time and sense, after his death, in which his diary will be read, explaining 'I will reply to your letter very soon. By now, you will understand why my reply fails to provide answers to all the questions you asked' (n9d 283). Both Frobisher and Subaru's writings emerge in relation to Sixsmith and Takara's readings. Frobisher and Subaru are already aware that these readings will declare their moments of writing impossible: Sixsmith and Takara will read the letter and the diary only when Frobisher and Subaru are dead and writing can no longer take place. It is nonetheless this very impossibility which allows their deaths to be written and to be read.

Mitchell's novels attempt to isolate a moment of writing, referring to acts of composition and claiming to tell the truth of the process from which they originate. However, this origin cannot be grasped; it cannot be separated from the product it composes. We repeatedly read writing's presence as past. Equally, however, no product can deny its production. Even if we do not grasp composition, we 'glimpse' it. And as we do so, our position is thrown into relief; the moment of reading becomes apparent. Our inability to read the moment of writing is not a failure, but a telling inevitability which reveals the very condition of a writing whose movements remain always to be read. 
Right at the very beginning, I told you I had rewritten my paper and erased the references to Barthes, Derrida and Wood. I lied. Those introductory paragraphs were in fact the very first I wrote. This was always to be an article about Derrida's 'Force and Signification' and its absence was, from the first, decidedly central.

Given that the writing by which it is composed is never fully present, we must accept 'the impossibility of [the work] ever being present, of its ever being summarized by some absolute simultaneity or instantaneousness. This is why, as we will verify, there is no space of the work, if by space we mean presence and synopsis' ${ }^{16}$ The work is never yet determined. And yet the literary criticism that would treat of this work has, for Derrida, 'already been determined, knowingly or not, voluntarily or not, as the philosophy of literature.'. ${ }^{17}$ As a 'philosophy', literary criticism speaks frankly-detached and definitive-claiming an authoritative tone. It claims to know the text about which it writes, proceeding as though both its rules and its object of study were laid out in advance. It thus disaffirms its role in the constitution of this textual object which is in fact, as we have shown, determined (and necessarily compromised) only at the point at which it is read.

Criticism institutes itself at a false distance from the reading and writing upon which it would comment; Wood writes that 'It is a frequent pretension of critical writing to imply that its significance depends on hypostatizing the movements of writing that get critical activity started in the first place $\cdot{ }^{18}$ Wood, on the other hand, pursues a critical writing conscious of its always-implicated investments. Derrida, too, challenges us to rethink criticism; he declares that

\section{Emancipation from this language must be attempted. But not as an attempt at emancipation from it, for this is impossible unless we forget our history. Rather, as the dream of emancipation. Nor as emancipation from it, which would be meaningless and deprive us from the light of meaning. Rather, as resistance to it, as far as possible. ${ }^{19}$}

We cannot reject the language of criticism for another; such a gesture is neither possible nor desirable. Instead, we must pursue the 'dream' of an inevitably failed attempt at 'emancipation'. For Derrida and Wood, 'writing' marks this already-failed attempt. By exhorting us to go 'all the way to writing' they propose a more writing-centred mode of criticism, knowing that the movements of writing do not present a simple alternative. We must engage ourselves in a writing always already conscious of its impossibility.

It is therefore fundamental to keep the movement of writing open; the writing Derrida and Wood laud must remain a productive dilemma with which we are never yet finished. Thus, it is always necessary to reinvigorate, through the movements of reading, the writing of 'Force and Signification', as 'All the Way to Writing' does so well, and to see its gestures totally anew. Even-and perhaps crucially-without mentioning them explicitly, my project here has been to trace these movements through a reading of Mitchell's novels.

\section{St. Catherine's College, University of Oxford}




\section{Notes}

1. Support for the research and writing of this article was provided by a doctoral award from the Arts and Humanities Research Council (AHRC).

2. Roland Barthes, S/Z, trans. by Richard Miller (New York: Hill and Wang, 1974), p. 4.

3. Barthes, p. 5, Barthes's italics.

4. Maurice Blanchot, The Infinite Conversation. trans. by Susan Hanson, (Minnepolis and London: University of Minnesota Press, 1993), p. 397.

5. Wood's 'all the way to writing' translates Derrida's 'jusqu'à l'écriture'. Her translation differs from that given by Alan Bass in Writing and Difference which renders Derrida's phrase as 'To the point of embracing it [force] as writing', Jacques Derrida, 'Force and Signification', in Writing and Difference, trans. by Alan Bass (London: Routledge \& Kegan Paul, 1978), pp. 3-30 (p. 28).

6. Sarah Wood, 'All the Way to Writing', Angelaki, 12 (2007), 137-47 (p. 146)

7. Wood, p. 146, Wood's italics.

8. David Mitchell, Ghostwritten: A Novel in Nine Parts (London: Sceptre, 1999), p. 270 (hereafter $G$ ). Further references to this novel are given after quotations in the text.

9. David Mitchell, number9dream (London: Sceptre, 2001), p. 228 (hereafter $n 9 d$ ). Further references to this novel are given after quotations in the text.

10. David Mitchell, Black Swan Green (London: Sceptre, 2006), p. 4 (hereafter BSG). Further references to this novel are given after quotations in the text.

11. Thomas Jones, 'Outfoxing Hangman', Times Literary Supplement, 11 May 2006, 34-35 (p. 34).

12. Stephen Abell, 'How to Get to the Ker-Bam', Times Literary Supplement, 27 February 2004, 21-22 (p. 22).

13. Patricia Waugh, Metafiction: The Theory and Practice of Self-Conscious Fiction (London and New York: Methuen, 1984), p. 19.

14. David Mitchell, Cloud Atlas (London: Sceptre, 2004), p. 166 (hereafter CA). Further references to this novel are given after quotations in the text.

15. Laurence Sterne, The Life and Opinions of Tristram Shandy, Gentleman, ed. by Christopher B. Ricks (Harmondsworth: Penguin Books, 1976), p. 268. The novel was originally published as nine volumes between 1759 and 1767 .

16. Derrida, p. 14, Derrida's italics.

17. Derrida, p. 28, my italics.

18. Wood, p. 143.

19. Derrida, p. 28, Derrida's italics.

\section{Works Cited}

Abell, Stephen, 'How to Get to the Ker-Bam', Times Literary Supplement, 27 February 2004, pp. 21-22

Barthes, Roland, S/Z, trans. Richard Miller (New York: Hill and Wang, 1974)

Blanchot, Maurice, The Infinite Conversation, trans. by Susan Hanson (Minnepolis and London: University of Minnesota Press, 1993)

Derrida, Jacques, 'Force and Signification', in Writing and Difference, trans. by

Alan Bass (London: Routledge \& Kegan Paul, 1978), pp. 3-30

Jones, Thomas, 'Outfoxing Hangman', Times Literary Supplement, 11 May 2006, pp. 34-35

Mitchell, David, Black Swan Green (London: Sceptre, 2006)

-_-, Cloud Atlas (London: Sceptre, 2004)

_-_, Ghostwritten: A Novel in Nine Parts (London: Sceptre, 1999) 
- - , number9dream (London: Sceptre, 2001)

Sterne, Laurence, The Life and Opinions of Tristram Shandy, Gentleman, ed. by Christopher B. Ricks (Harmondsworth: Penguin Books, 1976)

Waugh, Patricia, Metafiction: The Theory and Practice of Self-Conscious Fiction (London and New York: Methuen, 1984)

Wood, Sarah, 'All the Way to Writing', Angelaki, 12 (2007), 137-47 